Acta Technologica Agriculturae 4

Nitra, Slovaca Universitas Agriculturae Nitriae, 2016, pp. 89-95

\title{
IMPLEMENTATION OF STATISTICAL METHODS AND SWOT ANALYSIS FOR EVALUATION OF METAL WASTE MANAGEMENT IN ENGINEERING COMPANY
}

\author{
Renáta ZÁHORSKÁ1*, Ladislav NOZDROVICKY์' , L’udovít MIKULÁŠIK² \\ ${ }^{1}$ Slovak University of Agriculture in Nitra, Slovak Republic \\ ${ }^{2}$ RIBE Slovakia, k. s., Nitra factory, Slovak Republic
}

\begin{abstract}
This paper presents the results of the waste management research in a selected engineering company RIBE Slovakia, k. s., Nitra factory. Within of its manufacturing programme, the mentioned factory uses wide range of the manufacturing technologies (cutting operations, metal cold-forming, thread rolling, metal surface finishing, automatic sorting, metrology, assembly), with the aim to produce the final products - connecting components (fasteners) delivered to many industrial fields (agricultural machinery manufacturers, car industry, etc.). There were obtained data characterizing production technologies and the range of manufactured products. The key attention is paid to the classification of waste produced by engineering production and to waste management within the company. Within the research, there were obtained data characterizing the time course of production of various waste types and these data were evaluated by means of statistical method using STATGRAPHICS. Based on the application of SWOT analysis, there is objectively assessed the waste management in the company in terms of strengths and weaknesses, as well as determination of the opportunities and potential threats. Results obtained by the SWOT analysis application have allowed to come to conclusion that the company RIBE Slovakia, k. S., Nitra factory has well organized waste management system. The fact that the waste management system is incorporated into the company management system can be considered as an advantage.
\end{abstract}

Keywords: engineering production; technologies; waste management; multi-factor analysis; SWOT analysis

Agricultural machines can be considered as the most important tools in agricultural production. Agricultural machines and equipment consist of many components, which have to work together. Connecting parts, first of all the screws, play an important role in the field of machine components and they are widely produced by engineering companies. Within the Slovak Republic, the engineering production significantly contributes to increasing of the gross domestic product.

Considering the development of the engineering production in the Slovak Republic, an attention will be paid also to the impacts of industrial engineering production on environment. It is especially important, because the industrial engineering production leads to production of various kinds of waste with a negative impact on the environment.

According to Paulová (2009), in order to reduce industrial waste production, attention must be paid to the product quality. The product quality depends on quality of manufacturing process. Butner et al. (2008) state that individual manufacturing companies should focus on timely investment in implementation of environmentallyfriendly technologies. Bašta et al. (2005) mention that the lowest value of waste production in manufacturing process presents one of the essential features of the quality manufacturing process. The waste occurs alongside the life cycle of each civilisation. As stated by Klinda and Lieskovská (2009) in The State of Environmental Report of the Slovak Republic, a technical development in the engineering industry leads to increase in waste production. According to the legislation, waste is whatever the owner wants to get rid of; or also whatever that shall be eliminated or disposed of in order to provide healthy living conditions and environment protection. The waste shall be disposed of in accordance with requirements of local regulations. Badida et al. (2001) state that the waste can be present in various chemical composition and forms. The waste classification is based on Waste Catalogue in accordance with Decree No. 365/2015. Furthermore, the issues of waste are regulated also by Decree No. 129/2004 and Decree No. 284/2001, section. 2, paragraph 4. According to Báreková (2014), the waste can be grouped by several criteria - for example according to economic activity, composition, utilisation, disposal methods, environmental risks. Kuraš (1993) states that majority of chemical processes is accompanied with side reactions representing the most frequent source of the waste; furthermore, raw materials used for chemical industry contain a significant amount of impurities which transforms to waste during processing. The waste is classified as follows: hazardous waste (category $\mathrm{N}$ ) is a type of waste which can be threat to population health and environment due to its properties; special waste (category $Z$ ) is a waste requiring special handling, especially because of the economical or environmental reasons; and other waste (category O) representing group of waste without any properties, which are considered hazardous. It is a group representing a significant risk to environment. This risk results from the 
accumulation of large volume of this kind of the waste, not from its chemical composition.

Badida et al. (2001) state that individual waste kinds are categorized by N, Z, O classification in the relevant catalogue and are grouped into the following groups by their origin: plant and animal waste (rests of food, feed, plant and animal products, waste from breeding, butchery and processing, rests of leather and vachette, plant waste, wooden waste, waste from cellulose, paper, cardboard and so on), mineral waste including waste from treatment processes (waste from smeltery, power industry and engineering not containing metal elements, waste containing metals - iron, non-ferrous metal, sludge with metal elements); and wastes from chemical processes (oxides, hydroxides, salts, acids, plant protection waste, pesticides, pharmaceutical waste, crude oil processing and utilisation waste, coal treatment waste, gas and crude oil transportation waste, organic solvent waste, coating waste, waste from binders, sealants, textile waste). Regarding the increase in waste amount, Lumnitzer et al. (2007) emphasize a need to improve the waste management in engineering companies. Only with this approach, it is possible to assure sustainable development in the engineering industry (Muránsky and Badida, 2000). According to Richter (2009), thereby an important task of the industry - to achieve the cleaner manufacturing processes - will be solved.

\section{Material and methods}

\section{Characteristics of the selected engineering company and overview on manufacturing technologies used in this company}

In our research, we paid the attention to the problems of the waste management in the selected engineering company RIBE Slovakia, k. s., Nitra factory. The mentioned factory provides wide range of the manufacturing technologies (cutting operations, metal cold-forming, thread rolling, metal surface finishing, automatic sorting, metrology, assembly), with the aim to produce the final products - connecting components (fasteners). Based on the communication with the RIBE Slovakia, k. S., Nitra factory, there was obtained detailed information on production technologies and the range of manufactured products. The key focus was put on the classification of waste produced by engineering production and on company waste management. There is detailed analysis on the platform determining the waste management in accordance with current legislation. In our research, there were collected and obtained the data characterizing the time course of production of various types of waste, and these data were evaluated by means of statistical methods based on software STATGRAPHICS.

\section{Analysis of variance of values characterizing the waste generation in the selected company}

This part of our research is focused on the analysis of variance based on an assumption, that observations of stochastic variable $Y$ are independent and have normal distribution with constant variance that does not depend on the treatment method. We assume that the measurements of certain experiment are distributed into groups (classes) by A levels. According to Obtulovič (2010), the treatment means application of various manufacturing technologies, different methods of material forming and so on. In our case, the term "treatment" means the individual kinds of waste and years. Data on individual classes (levels) $A_{1}, A_{2}, \ldots$ $A_{m}$ have following count $r_{1}, r_{2} \ldots, r_{m}$ while a total sum of measurement quantity is equal to $n$, i.e. $n=\sum_{i=1}^{m} r_{i}$. If there is the same quantity of measurements at each $A$ level of treatment, the experiment is balanced what is valid in our case, too. If the quantity of measurements varies, the experiment is unbalanced. Assuming the same quantity of measurement within each treatment $A_{i}$, the measured data from single stage classification can be arranged in a table 1.

Based on measured values, it is possible to observe whether the mean values of individual treatments of $A$ levelsdiffer; this condition can be expressed by symbolic formulation of zero hypothesis as follows:

$$
H_{0}: \mu_{1}=\mu_{2}=\ldots=\mu_{m}
$$

respectively by means of effects $H_{0}: \alpha_{1}=\alpha_{2}=\ldots \alpha_{m}=0-$ for model with solid effects.

In first case (zero hypothesis), we support that the mean values of individual treatment of $A$ levels are equal; in the second case, the effects of individual treatment of $A$ levels have the same (i.e. zero) impact on the stochastic variable $Y$. An alternative hypothesis denies the zero hypothesis, i.e. at least one mean value $\mu_{i}$ is not equal to others; these values might be identical or none of them is equal to others.

The testing criterion is based on distribution of total variability into variability among classes and within classes, i.e.:

$$
\sum_{i=1}^{m} \sum_{j=1}^{r}\left(y_{i j}-y_{. .}\right)^{2}=\sum_{i=1}^{m} \sum_{j=1}^{r}\left(y_{j}-y_{i \bullet}\right)^{2}+r \sum_{i=1}^{m}\left(y_{i \bullet}-y_{. \bullet}\right)^{2}
$$

\begin{tabular}{|c|c|c|c|}
\hline Treatment $A$ & $Y_{i j}$ & Sum of $Y_{i}$ values. & Mean value of $Y_{i}$. \\
\hline $\begin{array}{l}1 \\
2 \\
\cdot \\
\cdot \\
\cdot \\
m\end{array}$ & $\begin{array}{c}Y_{11}, Y_{12} \ldots Y_{1 r} \\
Y_{21}, Y_{22} \ldots Y_{1 r} \\
\cdot \\
\cdot \\
Y_{m 1}, Y_{m 2} \ldots Y_{m r}\end{array}$ & $\begin{array}{c}Y_{1} . \\
Y_{2} \\
\cdot \\
\cdot \\
\cdot \\
Y_{m}\end{array}$ & $\begin{array}{l}Y_{1} \\
Y_{2} \\
\cdot \\
\cdot \\
\cdot \\
Y_{m}\end{array}$ \\
\hline Total & & $Y .$. & $Y .$. \\
\hline
\end{tabular}

Table 1 Single stage classification of values $y_{i j}$ 
Element $\sum_{i=1}^{m} \sum_{j=1}^{r}\left(y_{i j}-y_{. .}\right)^{2}$ is marked as $S$, it has $m \times r-1$ degrees of freedom and expresses an estimation of total variability of a stochastic variable $Y$, i . e $. s_{2}=\frac{s}{m \times r-1}$.

Element $\sum_{i=1}^{m} \sum_{j=1}^{r}\left(y_{i j}-y_{i \bullet}\right)^{2}$ is marked as $S_{r}$ it has $n-m$ degrees of freedom and expresses a variability within classes (or a residual variability) $S_{r^{2}}=\frac{S_{r}}{n-m}$.

Element $r \sum_{i=1}^{m}\left(y_{i \bullet}-y_{. .}\right)^{2}$ is marked as $S_{1}$ and has $m-1$ degrees of freedom and expresses variability among the treatment (classes) $s_{1^{2}}=s \frac{s_{1}}{m-1}$.

To verify the zero hypothesis, following value can be used as a testing criterion:

$$
F \frac{s_{1^{2}}}{S_{r^{2}}}
$$

Considering the selected value of confidence $\alpha$, this value has $F$ - distribution with $v=(m-1 ; n-m)$ degrees of freedom.

If the zero hypothesis is voided and the alternative hypothesis is accepted, we need to determine, which treatment of $A$ levels are statistically significantly different and which are similar (the same). Then, the analysis of variance will be completed by means of other evaluation method called contrast testing. For this purpose, we have used LSD contrast testing.

\section{SWOT analysis for evaluation of the level of the waste management in given engineering company}

For the selected engineering company - company RIBE Slovakia, k. s. located in Nitra, there will be implemented SWOT analysis in order to characterize the following attributes:

- strengths - internal (interior) attributes or parameters of the company, which allow to reach the aims in the field of the waste management;

- weaknesses - internal (interior) attributes or parameters of the company, which complicate and impede the reaching of aims in the field of the waste management;

- opportunities - external conditions, which can help to reach the aims in the field of the company waste management;

- threats - external conditions, which can complicate and endanger reaching of the aims in the field of the company waste management.

In order to realize the SWOT analysis, there will be used the data given by the company.

\section{Results and discussion}

\section{Analysis of variance characterizing the waste production in the selected company using Statgraphics software}

Using the data on amount and classification of the waste generation provided by RIBE Slovakia, k. s. company, an

Table 2 Dangerous waste $(\mathrm{N})$ - total breakdown of dangerous waste production during monitored period

\begin{tabular}{|c|c|c|c|c|c|c|c|c|}
\hline \multirow[t]{2}{*}{ No. } & \multirow{2}{*}{$\begin{array}{l}\text { Waste } \\
\text { catalogue } \\
\text { number }\end{array}$} & \multirow[t]{2}{*}{ Type of waste } & \multicolumn{6}{|c|}{ Amount of waste, $\mathbf{k g}$} \\
\hline & & & year 2010 & year 2011 & year 2012 & year 2013 & year 2014 & year 2015 \\
\hline 1 & 080317 & used printer cartridges & 20 & - & - & 50 & - & - \\
\hline 2 & 110105 & acidic bating liquors & - & - & - & 940 & - & 130 \\
\hline 3 & 110107 & alkali bating liquors & 3200 & 2260 & 3270 & 1170 & 1200 & 210 \\
\hline 4 & 110108 & sludge from phosphating treatment & - & - & - & 340 & - & 220 \\
\hline 5 & 120109 & cutting emulsions & 36190 & 43950 & 38740 & 35660 & 54380 & 45600 \\
\hline 6 & 130205 & non-chlorate mineral lubricating oils & 13740 & 12040 & 7840 & 7860 & 5390 & - \\
\hline 7 & 140603 & other solvents and solvent mixtures & 140 & 60 & 160 & 120 & 130 & 90 \\
\hline 8 & 150110 & $\begin{array}{c}\text { packs with rests of dangerous } \\
\text { materials }\end{array}$ & 10 & 50 & 90 & 30 & 30 & - \\
\hline 9 & 150202 & cleaning rag absorbents & 6490 & 8990 & 9240 & 10150 & 10990 & 14730 \\
\hline 10 & 160213 & $\begin{array}{l}\text { rejected equipment containing } \\
\text { dangerous parts }\end{array}$ & 30 & 150 & 20 & 10 & - & - \\
\hline 11 & 160508 & rejected chemicals & 830 & 1990 & - & 870 & 670 & - \\
\hline 12 & 160601 & lead batteries & 40 & - & 130 & 10 & 740 & - \\
\hline 13 & 190813 & $\begin{array}{l}\text { sludge with dangerous substances } \\
\text { from other industrial water treatment } \\
\text { processes }\end{array}$ & 3730 & 5190 & 5390 & 4210 & 4850 & 4080 \\
\hline Total & 64420 & 74680 & 64880 & 61420 & 78380 & 65060 & - & - \\
\hline
\end{tabular}

Source: company RIBE Slovakia, k. s., plant Nitra 
Table 3 Double factor analysis of variance

\begin{tabular}{|l||c|c|c|c|c|}
\hline Variability & Sum of squares & Degrees of freedom & Mean squares & Testing characteristics & $P$-value \\
\hline A: name of waste & 0.134478 & 2 & 0.0672389 & 0.98 & 0.4075 \\
\hline B: year & 1.15698 & 5 & 0.231396 & 3.38 & 0.0477 \\
\hline Residual & 0.683856 & 10 & 0.0683856 & & \\
\hline Total & 1.97531 & 17 & & & \\
\hline \multicolumn{2}{r}{ Source: own data obtained by means of STATGRAPHICS software }
\end{tabular}

analysis for certain time period (2010-2015) was performed. The data necessary for analysis of an operation of waste management system were provided by environmental management unit of RIBE Slovakia, k. s. company.

\section{Analysis of production of general waste to be recycled}

The purpose of the analysis was to find whether there are significant differences between individual types of waste for recycling during monitored period 2010-2015 using the statistical tools. Multifactor analysis of variance was used. The results show that there are no statistically significant differences between amounts of produced waste for recycling $(P$-value $=0.4075$, Table 3$)$. However, the significant difference in waste amount has been observed during monitored years ( $P$-value $=0.0477$ ), as presented in Table 2. Year 2015 differs significantly in waste amount in comparison to previous years. In this year, there was produced $0.91 \mathrm{t}$ of waste for recycling. A mean amount of waste produced in previous years ranged from $0.21 \mathrm{t}$ to $0.26 \mathrm{t}$.

This significant difference in amount of the produced waste for recycling in 2015 results especially from dealing with the semi-products. It is caused by the fact that RIBE Slovakia, k. s. started to supply large engineering company with final products.

Main manufacturing programme is represented by fixing components, especially screws made by cold forming of the wire. There is a group of screws manufactured as semiproducts and delivered to the head company for finishing in big boxes containing approximately 20000 pieces. When the finishing process is completed, the products are delivered back to the company in foil package in order to prevent damaging. These fixing parts and screws will be then unpacked and the required quantity of pieces (100 or 200 pieces, as defined by the customer) will be placed into plastic boxes delivered by the engineering company. The products are counted by the sorting machine detecting for possible deviations in size. Thereby a great amount of foil and cardboard waste used for product packing is produced by RIBE Slovakia k. s. company in Nitra plant. The cardboard waste comes from the packing used for screws because they are packed together with washers and these parts must be packed into cardboard boxes.

\section{Analysis of general waste production}

If another kind of waste (ferrous saw dust) will be included into the analysis in addition to waste for recycling, the result will be affected as follows. The amounts of individual kinds of waste differ significantly $(P$-value $=0.0000$, Table $5)$, however the differences within monitored period are not significant ( $P$-value $=0.4288$, Table 5$)$. It was this kind of waste what caused significant differences, (a mean value of ferrous saw dust was $258.1 \mathrm{t}$, Table 6); the mean amounts of other wastes ranged from $0.235 \mathrm{t}$ to $0.445 \mathrm{t}$.

Table 4 Method of multiple comparison - LSD contrast testing

\begin{tabular}{|l||c|c|c|}
\hline Year & Quantity of observations & Mean value & Homogeneity of groups \\
\hline \hline 2013 & 3 & 0.21 & $X$ \\
\hline 2010 & 3 & 0.22 & $X$ \\
\hline 2011 & 3 & 0.23 & $X$ \\
\hline 2012 & 3 & 0.25 & $X$ \\
\hline 2014 & 3 & 0.26 & $X$ \\
\hline 2015 & 3 & 0.91 & $X$ \\
\hline
\end{tabular}

Source: own data obtained by means of STATGRAPHICS software

Table 5 Double factor analysis of variance

\begin{tabular}{|l||c|c|c|c|c|}
\hline Variability & Sum of squares & Degrees of freedom & Mean squares & Testing characteristics & $P$-value \\
\hline A: name of waste & 298963 & 3 & 99654.4 & 160.59 & 0.0000 \\
\hline B: year & 3235.8 & 5 & 647.159 & 1.04 & 0.4288 \\
\hline Residual & 9308.4 & 15 & 620.56 & & \\
\hline Total & 311507 & 23 & & & \\
\hline \multicolumn{2}{r}{} \\
\multicolumn{2}{r}{ Source: own data obtained by means of STATGRAPHICS software }
\end{tabular}


Table 6 Method of multiple comparison - LSD contrast testing

\begin{tabular}{|l||c|c|c|}
\hline Name of waste & Quantity of observations & Mean value & Homogeneity of groups \\
\hline Packs made of plastics PET bottles & 6 & 0.235 & $\mathrm{X}$ \\
\hline Plastic packs & 6 & 0.363333 & $\mathrm{X}$ \\
\hline Paper and cardboard packs & 6 & 0.445 & $\mathrm{X}$ \\
\hline Ferrous saw dust & 6 & 258.1 & $\mathrm{X}$ \\
\hline
\end{tabular}

Source: own data obtained by means of STATGRAPHICS software

\section{Analysis of dangerous waste production}

The multifactor analysis of variance has been also used to analyse the dangerous waste. In course of this analysis, we were observing very similar statistical significance of differences between kinds of dangerous waste and monitored years. The analysis showed that there are significant differences ( $P$-value $=0.0000$, Table 7 ) between kinds of the dangerous waste presented in Table 8 as well. The mean amounts of the dangerous waste varied from $11.67 \mathrm{~kg}$ to $42420 \mathrm{~kg}$. The most significant differences in quantity are present between the cutting emulsions (mean amount $=42420 \mathrm{~kg}$ ) and all other kinds of waste; and between cleaning rags absorbent (mean amount = $10098.3 \mathrm{~kg}$ ) and non-chlorate mineral lubricating oils (mean amount $=7811.67 \mathrm{~kg}$ ) and other waste.

The above table proves the significant differences between kinds of dangerous waste. Sludge with dangerous substances from other industrial water treatment processes, non-chlorate mineral lubricating oils, cleaning rags, absorbents and cutting emulsions represent the biggest part of the dangerous waste.

Implementation of SWOT analysis in evaluation of waste management system in the selected engineering company

According to the defined methodology, this part of the research was aimed on practical applying the SWOT analysis to evaluation of the waste management system in the selected engineering company. Based on the methodology, strengths, weaknesses, opportunities and threads have been assessed.

\section{Strengths}

RIBE Slovakia, k. s. company, plant Nitra has a perfectly organized waste management system focused on waste

Table 7 Double factor analysis of variance

\begin{tabular}{|l||c|c|c|c|}
\hline Variability & Sum of squares & Degrees of freedom & Mean squares & Testing characteristics \\
\hline \hline A: name of waste & $9.78233 \mathrm{E} 9$ & 12 & $8.15194 \mathrm{E} 8$ & 120.18 \\
\hline B: year & $1.74415 \mathrm{E} 7$ & 5 & $3.48831 \mathrm{E} 6$ & 0.0000 \\
\hline Residual & $4.07003 \mathrm{E} 8$ & 60 & $6.78339 \mathrm{E} 6$ & \\
\hline Total & $1.02068 \mathrm{E} 10$ & 77 & & \\
\hline
\end{tabular}

Source: Source: own data obtained by means of STATGRAPHICS software

Table 8 Method of multiple comparison - LSD contrast testing

\begin{tabular}{|l|c|c|c|}
\hline Name of waste & Quantity of observations & Mean value & Homogeneity of groups \\
\hline Used printer cartridges & 6 & 11.6667 & $\mathrm{X}$ \\
\hline Packs with rests of dangerous materials & 6 & 35.0 & $\mathrm{X}$ \\
\hline Rejected equipment containing dangerous parts & 6 & 35.0 & $\mathrm{X}$ \\
\hline Sludge from phosphating treatment & 6 & 93.3333 & $\mathrm{X}$ \\
\hline Other solvents and solvents mixtures & 6 & 116.667 & $\mathrm{X}$ \\
\hline Lead batteries & 6 & 153.333 & $\mathrm{X}$ \\
\hline Acidic bating liquors & 6 & 178.333 & $\mathrm{X}$ \\
\hline Rejected chemicals & 6 & 726.667 & $\mathrm{X}$ \\
\hline Alkali bating liquors & 6 & 1885.0 & $\mathrm{XX}$ \\
\hline $\begin{array}{l}\text { Sludge containing dangerous substances from } \\
\text { other industrial water treatment processes }\end{array}$ & 6 & 4575.0 & $\mathrm{X}$ \\
\hline Non-chlorate mineral lubricating oils & 6 & 7811.67 & $\mathrm{X}$ \\
\hline Cleaning rags, absorbents & 6 & 10098.3 & $\mathrm{X}$ \\
\hline Cutting emulsions & 6 & 42420.0 & $\mathrm{X}$ \\
\hline
\end{tabular}


related to individual manufacturing technologies, while this system is organically integrated into overall management system of the company. Based on this fact, the selected engineering company carries out its waste management in cooperation with DETOX s.r.o., Banská Bystrica, a professional working place for industrial waste registration and disposal.

Within the frame of this cooperation, the selected company has perfectly organized documentation of environmental policy emphasizing the issues of waste management and packing. The measures to be implemented in case of accident, such as waste management programme, identification sheets of dangerous waste, are prepared and documents necessary for decision making process of state administration are provided regularly. Furthermore, RIBE Slovakia, k. s. company, plant Nitra, in cooperation with DETOX s.r.o., Banská Bystrica also provides expertise related to waste, consultancy services on issues of Recycling fund, Act on Packing Materials etc., and carries out regularly state analysis of individual components of environment.

It can be clearly stated that operation of waste management system in the selected company respects current legislation, including following legal documents:

- Decree No. 365/ 2015 Waste Catalogue;

- Decree No. 366/ 2015 Waste Registry;

- Decree No. 370/2015 Rates for calculation of fees to be paid to the Recycling Fund, List of products, materials and equipment which are subject of fees to be paid to the Recycling Fund;

- Decree No. 371/2015 Execution of certain requirements of the Waste Act;

- Decree No. 372/2015 Waste Repositories;

- Decree No. 373/2015 Extended responsibility of manufacturers of reserved products and handling with reserved flows of the waste;

- Act No. 79/2015 on Waste, which revises and lists the programme documents of waste management system, defines measures for prevention of waste production, defines rights and obligations of legal entities and natural persons related to prevention of waste production, determines the terms of handling with waste and it defines precisely the extended responsibility of manufacturers.

The strength of the company includes also the fact that there is overall opinion in the company that an ability to satisfy the needs of the clients is not realized only by production or service provision, but also by active interest in overall reproduction cycle of products. The product quality will include all factors leading to the required results. It relates to the following attributes:

- quality of product (tangible product);

- quality of service (intangible product);

- quality of processes and sources (machines and equipment, information, working environment);

- quality of management system.

In order to prove its interest in client and demonstrate a high quality in field of manufacturing of connecting products, the company focused on obtaining the following certificates:
- Quality management system of RIBE Slovakia, k. s. company, plant Nitra meets the requirements of international standard ISO 9001:2008 for following activities: manufacturing of connecting products, certificate number: Q-0143/13, date of issuance: 11.01. 2013, date of initial approval: September/30/2000.

RIBE Slovakia, k. s. company, plant Nitra obtained also a certificate issued by international organization NSF International Strategic Registration, confirming that quality management system of RIBE Slovakia, k. s. company, plant Nitra meets the requirements of international standard ISO/TS 16949: 2009 for following activities: manufacturing of connecting products, certificate number: IATF 0232996, date of issuance: March/03/2016.

\section{Weaknesses}

Resulting from detailed analysis of waste management conditions in selected engineering company RIBE Slovakia, k. s., plant Nitra, we can state that overall company waste management system has no weaknesses in general. The fact that the company does not have certificate of Environmental management system (EMS) according to STN EN ISO 14001 can be considered as its only weakness. This standard specifies requirements to the environmental management system but it is not obligatory for the organizations. Ministry of Environment of the Slovak Republic is a gestor of EMS implementation in Slovakia throughout basic and standardizing provision. Technical standardizing commission TNK No. 72 called Environmental management has been established at Slovak Institute of Technical Standardization.

\section{Opportunities}

Due to its capabilities, arrangement, control method and overall focus of activity, the waste management system in the engineering company RIBE Slovakia, k. s., plant Nitra provides possibility to cope with increasing amount of waste resulting from expansion of the engineering production in this company while preserving the product assortment. It can lead to decrease in intervals between waste transports and this issue should be solved by organizational measures.

\section{Threats}

Certain threats to the waste management system in the engineering company Slovakia, k. s., plant Nitra can be caused by quick change in assortment of materials used for manufacturing of new product kinds, change or extension of the manufacturing technologies, utilization of new types of cooling or lubricating oils etc. Taking into account the above considerations, it should be emphasized that the selected company is a consolidated company with stabilized park of manufacturing technologies. Based on these facts and considering given conditions, it can be claimed that it is not probable that the waste management system of the selected company would be jeopardized by certain external factors. 


\section{Conclusions}

The technologies of engineering industry provide not only manufacturing of the engineering products. Its technologies have significant impact on the environment. The increase in the industrial production has a dominant impact on the environment. These impacts can not be neglected, since these technologies have direct impact on the environment where the humans live and work. Based on formulated objectives, our research is oriented on observation of impacts of engineering production on the waste production, focusing on waste management system in the selected engineering company RIBE Slovakia, k. s. in Nitra. This company can be considered as up-to-date engineering company, focused on manufacturing of metal products, metal processing, pressing, cutting and rolling of metals, milling operation, turning operation and other metal processing works. The results of our research confirmed the significance of efficient waste production reduction, because the waste production influences the company economic development.

\section{References}

BADIDA, M. - MAJERNÍK, M. - ŠEBO, D. - HODOLIČ, J. 2001.Strojárska výroba a životné prostredie. Košice :TU, 2001. ISBN 80-7099-695-1.

BAŠTA, J. - HRDLIČKA, F. - KOLÁŘOVÁ, H. 2005. Člověk a prostředí. Praha : Česká technika - nakladatelství ČVUT, 2005. 129 pp. ISBN 80-01-03329-5.

BÁREKOVÁ, A. 2014. Odpadové hospodárstvo. p. 5. ISBN: 978-80-552-1149-7.

BUTNER, K. - GEUDER, D. - HITTNER, J. 2008. Mastering carbon management: Balancing trade-offs to optimize supply chain efficiencies. IBM Global Business Services, IBM Institute for Business Value, Somers, NY 10589, USA, 2008. 13 pp.

KLINDA, J. - LIESKOVSKÁ, Z. 2009. Správa o stave životného prostredia Slovenskej republiky v roku 2008. Ministerstvo životného prostredia Slovenskej republiky. Bratislava : Slovenská agentúra životného prostredia, 2009. 308 pp. ISBN 978-80-88833-53-6.

LUMNITZER, E. - BADIDA, M. - ROMÁNOVÁ, M. 2007. Hodnotenie kvality prostredia. 1. ed. Košice : SjF TU, 2007. 275 pp. ISBN 978-80-8073-836-5.

MURÁNSKY, J. - BADIDA, M. 2000. Trvalo udržatel'ný rozvoj v strojárstve. Košice : Vienala, 2000.

OBTULOVIČ, P. 2010. Bioštatistika. Nitra : SPU, pp. 87-90. ISBN 978-80-552-0397-3.

RICHTER, M. 2009. Perspektiva průmyslu - čistší produkce. In Strojárstvo/Strojírenství, 2009, no. 1, pp. 9-11. ISSN 1335 - 2938. 